\title{
New Perspective on Portfolios in EFL Classrooms: Portfolio as
}

\section{an Autobiographical Text}

\author{
Jokha Al Hosni ${ }^{1 *}$ \\ ${ }^{1}$ Sultan Qaboos University, Muscat, Oman \\ *Jokha Al Hosni, E-mail: alhosnij@squ.edu.om
}

Received: October 26, 2017 Accepted: November 5, 2017 Online Published: November 18, 2017

doi:10.22158/selt.v5n4p771 URL: http://dx.doi.org/10.22158/selt.v5n4p771

\begin{abstract}
This paper aims to define the term "portfolio" and its application in classrooms. Through reflecting on my personal experience with using the portfolio project with EFL students and exploring the related literature, some major challenges will be addressed. The main focus of this paper is to introduce the autobiographical approach in curriculum as an attempt to find new pathways to deal with these challenges.
\end{abstract}

Keywords

Portfolio, challenges, EFL, currere

\section{Literature Review}

The concept of portfolio is adopted from the field of fine arts in which portfolios are used to represent the artists' own work. It is a reflection of the depth and breadth of the artist's work and his artistic capacities in general (Moya \& O'Malley, 1994). Similarly, educators have used portfolios as a tool to measure the academic capacities of learners in a particular field and over a particular period of time. In the field of English Language Teaching (ELT), educators have realized the importance of implementing the portfolio approach as a learning tool and an alternative assessment to measure the linguistic abilities of (English as a second/foreign language) learners (Tannenbaum, 1997). It has proved its superiority over the traditional methods of assessment because it "employs strategies that ask students to show what they can do" compared with the traditional testing in which "students are evaluated on what they integrate and produce rather than on what they are able to recall and reproduce" (Tannenbaum, 1997). Hung (2009) also asserted that "portfolios provide an opportunity for learners to monitor their own progress and take responsibility for meeting goals" (p. 131). Yet, implementing the portfolio approach in ESL/EFL classrooms entails many potential problems. Investigating these challenges can help to find ways to eliminate them.

In this paper, portfolio will be repeatedly defined as a tool of learning and assessment in the classroom 
setting. Portfolio is "a compilation of students' work, which demonstrates how much effort they have put into their work, their progress and achievement in their learning, and their reflection on the materials chosen for the portfolio" (lau, n.d.). It is also defined as "a systematic and purposeful collection of learner's work that demonstrates achievement of learning outcomes over time (ESL Literacy Network, 2011). This tool was introduced in education in 1980 and, since then, it has gained a considerable attention as a learning and assessment tool (Aydin, 2010). It is obvious from the two definitions that using portfolios in ESL/EFL classrooms has some merits over the traditional methods of assessment. Lau (n.d.) asserted that:

Portfolio assessment... can evaluate students holistically based on the content of the portfolio on which the teachers and students agree. Moreover, it focuses greatly on individual differences. As language cannot be acquired overnight, the portfolio can give students a chance to build up their experiences in language learning, and this experience can motivate students to be more involved in the classroom (Para.7).

Lau summarizes the advantages of using portfolio in English language classrooms where students are second language learners and their proficiency in English needs time to develop. Aydin (2010) also pointed out that portfolio project in an EFL classroom can "encourage student empowerment, help learners analyze literary texts, write in a variety of styles, and demonstrate an awareness of the target language culture" (p. 477). Although portfolio is considered to be a tool for learning through which ESL learners practice the different language skills, many educators use it mainly as an authentic and accurate way to measure the learners' improvement (Moya \& O'Malley, 1994). The whole language approach developed by Chomsky and Goodson has strengthened the position of portfolio in language learning classrooms. This approach views language as a whole, because" breaking it into parts no longer maintains the nature of language itself" (Marhaeni, 2003, p. 56). Based on this approach, the teaching of language should be holistic and authentic, as learners are encouraged to use real-life incidents/experiences through which they practice the second language. This philosophy can be traced back to the philosophical teaching ideas of John Dewey, especially his theory of experience. Dewey asserted that an experience is "always what it is because of a transaction taking place between the individual and what, at the time, constitutes his environment" (Dewey, 1938, p. 43). In this way, experience "is the result of the exchange between an organism and its environment" (Aedo, 2002, p. 7). Individuals, as Dewey believed, need experience in their learning in order to foster the natural relation with their environment without which they cannot meaningfully function. Similarly, in the case of learning a second language, ESL/EFL learners cannot properly master the language, unless they connect it to authentic and personal experiences. Therefore, developing a learning portfolio can help ESL learners to produce a variety of work over an extended period of time that enables them to interact with and reflect on multiple learning experiences. Hence, Kohonen (2000) believed that the language portfolio can "promote the twin goals of the learner-centered curricula discussed by David Nunan (1988): (1) learning communication and (2) developing a critical awareness of language learning”. 
As a mainly written document, many educators have conducted studies to explore the effectiveness of using portfolios in ESL/EFL classrooms on elevating the level of writing anxiety among second language learners. Oztruk and Cecen (2007) pointed out in the conclusion section of their study that "The causes of writing anxiety are resolved through the nature of portfolio. Portfolio as an instructional practice far away from being a traditional, punitive, and judgmental approach to teaching L2 writing creates the melting point in which the affective variables related to writing anxiety melt" (p. 230). Portfolio gives learners the opportunity to write their work freely in a relaxing environment in which they encounter no stress.

Despite the aforementioned overview that illustrates the rationale behind using portfolio approach in ESL/EFL classrooms, implementing this learning and evaluating tool has entailed many noticeable challenges for language learners. To illustrate some of these prevalent challenges, I will first reflect on my own experience with using portfolio with my students in an intensive English language program.

\section{Investigating the Challenges of Using Portfolios in ESL/EFL Classrooms}

I have been teaching freshmen students in the English Foundation Program (EFP) at Sultan Qaboos University since 2010. These students join the university with different language proficiency levels ranging from false beginners to intermediate-level learners of the language. One of the FP courses' requirements is developing a portfolio which contains the following artifacts: An academic planner, a learning-goals checklist, a learning-goals statement midterm and end-of term reflection papers, weekly learning reflections and weekly vocabulary logs, as well as some documents/handouts which guide them on how to complete these artifacts. Throughout the semester, students are required to complete weekly learning reflection papers in order to demonstrate their independent learning in one of the language skills (reading, writing, listening, speaking). They are also required to create weekly vocabulary logs which should have ten new words with their dictionary definitions, parts of speech and sentence examples that illustrate the use of the words. It is worth mentioning here that the portfolio project weighs $10 \%$ of the total course grade and the students have a very busy schedule of 18 hours of English classes every week along with Math and IT courses. The program offers lots of extra-curricular activities in the four language skills for the students during the semester in order to help them find extra and new activities to reflect upon on a weekly basis. However, the following questions are worth considering to evaluate the efficacy of this project:

1- How can a portfolio project, given to this particular group of learners, be a learner-centered tool when they perceive it as a big burden over their shoulders and can never enjoy it, as they are overwhelmed by a couple of courses and assignments in their first year in college?

2- I believe, as discussed earlier in this paper, that portfolios can help students be more independent and responsible for their own learning. Paulson and Paulson (1992) asserted that portfolios can "be a powerful educational tool for encouraging students to take charge of their own learning". However, and based on the project's description offered previously, how can language learners with limited language 
proficiency and overwhelming academic tasks in their first year in college have control over their learning? How can they produce authentic learning experiences? As a real example, many of my students, even the most hard-working ones, have turned in the following learning-goals statement:

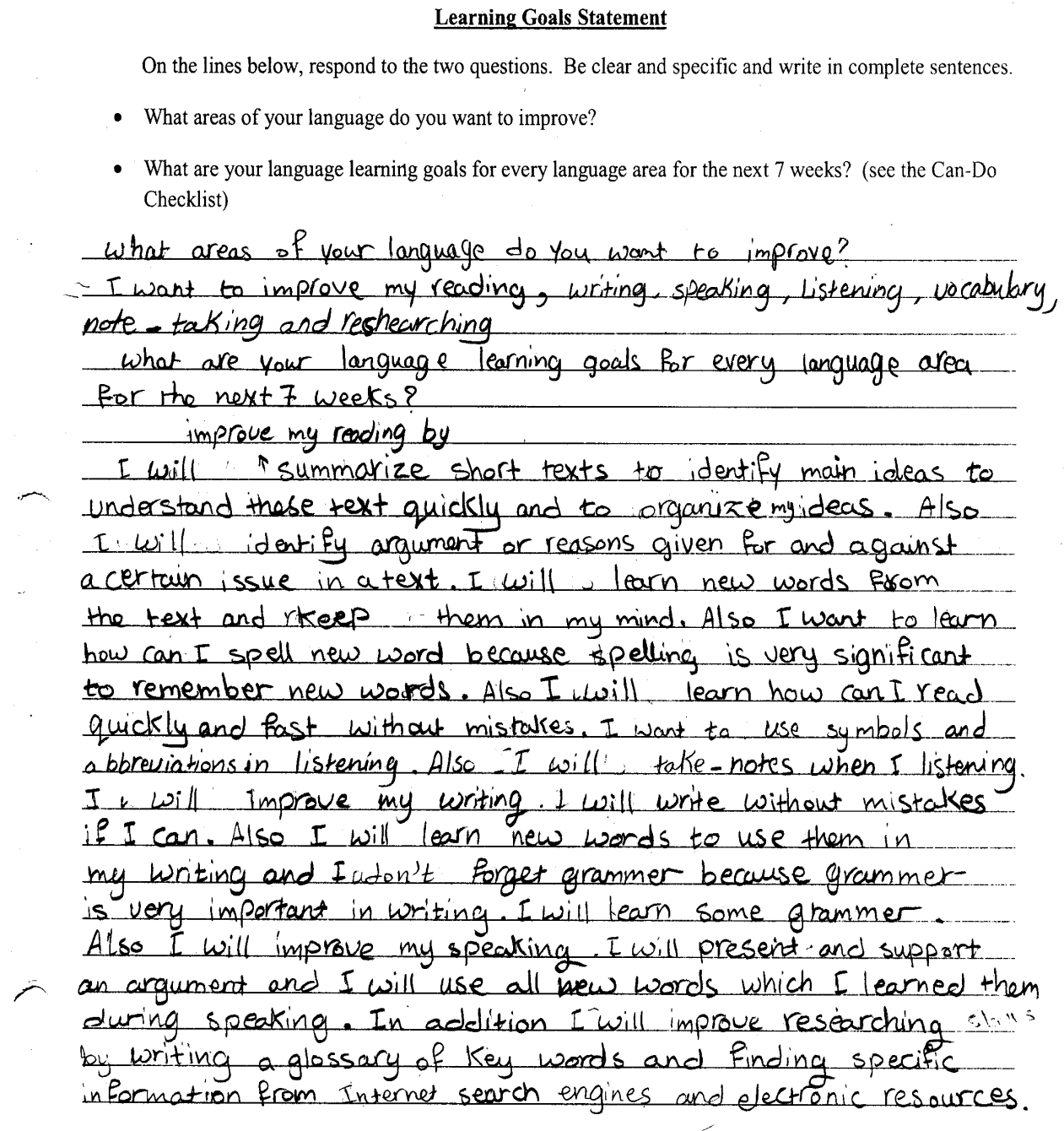

At first glance, the statement looks very authentic and indicates a level of self-awareness of what the learner wants to achieve and get from this course. However, looking at the handout provided by the program which contains the learning checklist makes you reconsider your first impression. Comparing the student's statement with the checklist, it is obvious that the student has copied all his goals from the checklist, apparently because the guidelines in the goals' statement ask him to follow the can-do checklist! This sample represents not only one of my students' work, but many of them.

How can I, as a teacher, guarantee the authenticity of students' portfolio work? It is highly legitimate, under the circumstances of this particular group of learners, to think that students may turn in copied work. This is what, in fact, happens when I sometimes find out at the end of the semester that few students submit work which is copied from each other (peers from other classes). Clerk et al. (2001) indicated this challenge by asserting that sometimes portfolios are considered nothing but "a Published by SCHOLINK INC. 
last-minute compilation of the required pieces placed in a folder not far different from the typical student permanent record" (p. 215).

The aforementioned questions are my reflection on my personal experience with using portfolio in my EFL classrooms. As a teacher, I can admit that although I believe that using portfolio is a very effective and empowering tool for both the teacher and his/her students, applying this tool blindly can harm the learners' academic progress. It is obvious from this experience with using portfolios that using this approach with second language learners is not an easy task. There are many common, and sometimes, hidden challenges which face both learners and teachers. The literature related to this topic has explored the main challenges faced by language learners during implementing the portfolio project.

Marhaeni (2003) recognized two major challenges with using portfolios. First, portfolios involve a risk-taking experience. It has been noticed by many teachers that their students usually exhibit hesitance towards working on their portfolios unless they get a direct guidance and approval from their teachers, despite the fact they already have evaluation checklists provided by their teachers at the beginning of the semester (Marhaeni, 2003). This can be attributed to the fact that this learning experience is quite novel to many students who never practice authentic learning, which is the core theme of constructivism orientation in learning, an orientation which "gives us an awareness of what we know and how we happen to know it, what it is to know something, and how developmental stages in our capacity to learn things change from one to another" (Oztruk \& Cecen, 2007, p. 222). It is obvious that learners are still afraid of deviating from the teacher model and; thus taking the risk of losing marks. They are not, or are not taught to be, willing enough to take the initiative and responsibility to try new experiences and reflect on them. They are, I believe, the victim of the banking model of traditional education. In his famous book, Pedagogy of the Oppressed, Freire (1972) criticized the traditional education in which learners are passive participants receiving whatever the teacher deposits in their heads. Freire used the term "Banking Model" to refer to this unnatural and unproductive relationship between the teacher and his/her students (Chan, 2012). Applying the portfolio approach can be an example of Problem Posing, the new model he suggested to overcome the banking model. Yet, it seems that students "are still very much product-oriented" and changing this attitude needs real efforts from teachers (Marhaeni, 2003).

The banking model which still exists in our educational systems may also be the reason behind the second challenge. Marhaeni (2003) argued that "expressing themselves as active learners who know what they need seems not yet a value to the students". He adds that students in the portfolio project usually feel reluctant to write a reflection on their own learning, because they don't have self-motivation to do so and/or they are accustomed to value formal tools of assessment which are based on teachers' judgments of the student's work. As a result, they have developed the belief that their personal interests are of no value in the classroom, a belief which Dewey fought against through his educational philosophy which places a great emphasis on the learners' interests and personal experiences in society. This philosophy can be clearly depicted in his book, Democracy and Education. 
The Language barrier is another challenge which makes portfolio a new burden upon the ESL/EFL learners. Although portfolio can explicitly help students to improve their language proficiency by encouraging them to practice the language skills (reading texts, writing, etc.), having the two challenges mentioned earlier can hinder them from enjoying and actively engaging with this new experience.

In their empirical study entitled, Portfolios as Sites of Learning: Conceptualizing the Connection to Motivation and Engagement, Clark et al. (2001) argued that in order to overcome the aforementioned challenges, educators need to reconsider the connection between portfolio as a learning tool and students' level of motivation and engagement. They asserted in the implications section of their study that:

Portfolios as material and social sites of learning provide a space within which students can negotiate their construction of self, task and fit a unique window through which we can view and understand these phenomena. Conceptualized in this way, motivation and engagement are best understood as social rather than individual phenomena, realized when students become fully participating members in communities of practice (p. 234).

This is a new lens through which we can, as educators and teachers, better deal with portfolios as a tool of learning that helps learners to engage actively in their learning. I believe that the first step in implementing the portfolio project is making students believe that their portfolios are a reflection of their own identity and a record of their interests and their interaction with their society. This idea can be explained more through highlighting the autobiographical approach in curriculum theory, an approach that attempts to view curriculum as an autobiographical text.

\section{Portfolio as an Autobiographical Text}

In his article, Working from Within, William Pinar has established the foundation of the autobiographical method (Pinar et al., 2008). In 1970s Pinar and Grumet used the term currere to refer to this new approach of perceiving curriculum which is the Latin infinitive of the word curriculum. In this approach curriculum is viewed as an "inner experience" in the form of biographies and autobiographies. The method of currere as an autobiography means studying the lived experience of individuals through a curricular context (Petrina, 2010). Pinar asserts that "the method of currere is not a matter of psychic survival, but one of subjective risk and social reconstruction, the achievement of selfhood and society in the age to come" (Petrina, 2010). This method has been developed primarily and used widely by educators who seek self-understanding as "a vehicle for personal emancipation and professional development" (Butt \& Raymond, 1989, p. 405). In this method, the learner is an individual who has an authority over his/her learning via using his/her own life incidents to shape his/her knowledge as an attempt to build a bright future. The autobiographer tries to understand how academic studies can help oneself to understand his/her own life (and vice versa) (Norquay, 2006).

Pinar identified four stages in the method of currere: 1) regressive, 2) progressive, 3) analytical, and 4) 
synthetical (Pinar et al., 2008). In the first stage, the learners get in touch with their past memories related to a particular theme in their life. In the second stage, they connect these memories to their future through "imagination and potentiality". Pinar (1975) pointed out that in the regressive stage the learner "returns to the past, to capture it as it was, and as it hovers over the present" (p. 8). In the analytical stage, the learners/autobiographers explore the connection between the past and future under the influence of their current reality. He "takes both photographs, and set them aside. What is left? Describe the biographic present, exclusive of the past and future, but inclusive of responses to both" (Pinar, 1975, p. 13). In the last stage, the autobiographer tries to "draw together from the continuity of time a sense of meaning in the present" (Autobiography \& Curriculum, n.d.). Pinar et al. (2008) indicated that Currere "reminds the child that he or she is distinct from the nonego, the curriculum" (p. 522). In other words, through the autobiographical approach, the learner uses his/her own life, identity, character, social backgrounds, etc. as a tool to help him/her get engaged with the curriculum, rather than making the formal curriculum stated by others the tool that guides his/her learning journey.

As mentioned earlier, using this approach is more common among teachers and educators who seek personal understanding of their educational career that helps them to identify and reconstruct their educational beliefs. A very small volume of research is conducted on how to utilize this approach with young learners in regular classrooms in schools or colleges. The only comprehensive work I have found in literature is the book written by Marilyn Doerr in 2004 entitled, Currere and the Environmental Autobiography. The author states that "I want to describe my classroom experiment with currere and how the students and I learned together that currere greatly enhanced our understanding of ecology" (p. 20). The author designed a one-year project, which he called the Environmental Autobiography (EA), with his senior high students based on the currere approach. The book documents the course's success from the author's point of view by illustrating how "the currere project brought an unprecedented richness and intensity to the ecology class, moving the students from "I know", to "I care", to "I want to do something about this" (Doerr, 2004). This has been enhanced by utilizing the four phases of currere. The author allowed the students to spend a whole month on each phase through bringing their personal experience with the physical world to words. Moving from one phase to the other, students started realizing the purpose behind this approach and they showed great interest in proceeding with the project. The author points out that this project helps the students to consider and live with five main critical themes: caring, insecurity and gender issues, egocentrism, politicization, and definitions of success.

What I really find very interesting is how this project encouraged the students to write freely, more enthusiastically and, thus creatively. The author states that:

Students from other classes came to ask me if student A had written over 100 pages and could they please see them, or that student B had actually had typed fifty pages himself - they didn't believe it (p. $30)$.

Inspired by Doerr's book, I believe that applying this method of currere in the ESL/EFL classroom 
portfolio project can be a very effective and rewarding way to overcome the aforementioned challenges. Clerk et al. (2001), in the long quote stated earlier, argued that portfolios can be a space through which learners reconsider their identities and, therefore, encourage them to get engaged with their projects. This would greatly help to overcome the challenges that face these learners during implementing the project. In ESL/EFL classrooms, learners have a wider space in which they can express their identity, reflect on personal experiences and bring in different readings that are of great interest to them. That is because in language portfolios, there is no specific content which students are required to work on as it is the case with science, religion, history or social studies subjects. They can select the sort of experiences they would like to work with as long as it allows them to practice the different language skills.

From my own experience with using portfolios with my students, I have noticed that learners don't have the motivation to get engaged with this project when they feel that portfolio is nothing but a new burden with lots of challenges. Via using the autobiographical approach, I believe that learners will love the project, as they feel that this document is a reflection of their own character and a space through which they can release some inner feelings, interests, frustrations and so on. To achieve this, it is important to" maintain an emphasis on the process aspects of portfolios, rather than simply the products or outcomes" (Clerk et al., 2001, p. 134). This can be done through encouraging students to enjoy working on the different artifacts of their portfolios. For instance, for the weekly learning reflections, the teacher can suggest different individual activities which reflect the personal interests of his/her students such as: writing a summary about a student's favorite book or movie or write about one of his/her unforgettable memories. In reading, the teacher can encourage them to read a story of their choice or an article about a topic related to their major and then reflects on what they learn from it. Similar ideas can be suggested for the other language areas. At the end of the semester, and instead of turning in a hard copy of their portfolios to the teacher, students should be encouraged to make a presentation and show the content of their portfolios to their classmates. Therefore, students feel more responsible for their portfolio, since it is a reflection of their identity or an autobiography more than just a record of their semester's work.

\section{A Suggested Plan for EFL Learners to Practice the Four Phases of Currere for Their Portfolio's Work}

As I mentioned earlier, I am teaching English for Academic Purposes courses (EAP) in which EFL learners are grouped according to their majors (Science, technology, education, medicine, etc.) Therefore, when applying currere approach, it is a good idea that the teacher thinks of materials and language content that might sound appealing to the learners. For example, with science EFL learners, the teacher can divide the class into three or four groups according to their scientific interests. Then, he/she can present reading texts or videos that involve contemporary scientific issues that can directly touch upon students' real lives and personal experiences. Students should implement the four phases of 
currere over a specific period of time. Each stage involves one written assignment that constitutes a certain proportion of the portfolio. Students can later speak to their groups about their experience with using each stage. By doing this, learners can realize the value of their work as it is directed towards their own life interests and as they feel that they have control over what they learn. It is due to the fact that they consciously make use of the content they are exposed to by adding their own input and interpret it the way which is truly meaningful to them.

\section{Conclusion and Recommendations}

In this paper I have investigated the challenges faced by ESL/EFL learners when implementing the portfolio approach. I have started the paper by defining portfolio as a learning and assessment tool and the incentives behind using it in the English as a second/foreign language classroom. The core theme of this paper is about exploring the potential problems of using portfolio project in EFL/ESL classrooms and trying to present a suggestion that may help to overcome these problems and; thus, making this new learning experience enjoyable and rewarding to both learners and teachers. Drawing on my personal experience with portfolios and what the related literature offers, the paper has outlined the major challenges this approach entails. As an attempt to find a new trajectory through which the language teacher can overcome the challenges associated with portfolios, the paper has introduced the autobiographical approach proposed by William Pinar as a novel lens to look at portfolios. Dealing with the learner's portfolio as an autobiographical text can undoubtedly encourage learners to actively engage with their portfolios and help them to improve their language proficiency.

Reflecting on my experience with portfolios and exploring a new method on how I can look at this learning tool from a different angle has inspired me with new strategies to follow with my students when implementing the portfolio project. I believe that new and more focused empirical studies should be devoted to this approach in language learning. These studies should focus on examining the impact of viewing portfolio as an autobiographical text on learners' engagement in the learning process.

\section{References}

Aedo, C. (2002). The value of experience in education: John Dewey. Retrieved from http://www.caedofu.tripod.com/cv/dee.pdf

Autobiography and Curriculum: Its theory and application to religious education in a millennial era. (n.d). Retrieved from http://www.old.religiouseducation.net/proceedings/Procario.pdf

Aydin, S. (2010). A qualitative research on portfolio keeping in English as a Foreign Language Writing. The Qualitative Report, 15(3), 475-488.

Butt, R. L., \& Raymond, D. (1989). Studying the nature and development of teachers' knowledge using collaborative autobiography. International Journal of Educational Research, 13(4), 403-419. https://doi.org/10.1016/0883-0355(89)90037-2

Cahn, S. M. (2012). Classic and Contemporary Readings in the Philosophy of Education. New York: 
Oxford University Press.

Clark, C., Chow-Hoy, T., Heter, R., \& Moss, P. (2001). Portfolios as sites of learning: Conceptualizing the connection to motivation and engagement. Journal of Literacy Research, 33(211), 212-241. https://doi.org/10.1080/10862960109548110

Dewey, J. (1938). Experience and Education. New York: Kappa Delta Pi.

Doerr, M. (2004). Currere and the Environmental Autobiography: A phenomenological approach to the teaching of ecology. New York: Peter Lang Pub Incorporated.

Hung, S. (2009). Promoting Self- assessment Strategies: An Electronic Portfolio Approach. The Asian ELT Journal Quarterly, 11(2), 129-146.

Kohonen, V. (2000). Students reflection in Portfolio assessment: Making language learning more visible. Babylonia. Retrieved from http://www.193.52.249.112/crdp/IMG/pdf/3-_Portfolio_ Assessment_V_Kohonen.pdf

Lau, S. (n.d). The Implementation of Portfolio Assessment in an ESL/EFL Classroom. Retrieved from http://www6.cityu.edu.hk/elc/edb/asl/Day\%202\%20session\%201/D2S1Preworkshop\%20reading.p df

Marhaeni, A. (2003). Portfolio assessment in a competency-based English as a Foreign Language (EFL) Instruction. IKIP, 51-62.

Moya, S., \& O’Malley, J. (1994). A portfolio assessment model for ESL. The Journal of Educational Issues of Language Minority Students, 13, 13-36.

Norquay, N. (2006). How playing the banjo helps me think about curriculum. Journal of the Canadian Association for Curriculum Studies, 4(1).

Oztruk, H., \& Cecen, S. (2007). The effects of portfolio keeping on writing anxiety of EFL Students. Journal of Language and Linguistic Studies, 3(2).

Paulson, L. F., Paulson, R. P., \& Meyer, A. C. (1991). What makes a portfolio a portfolio? Retrieved from http://www.stanford.edu/dept/SUSE/projects/ireport/articles/eportfolio/what\%20makes\%20a $\% 20$ portfolio\%20a\%20portfolio.pdf

Petrina, S. (2010). Currere: Curriculum as Method or Process. Retrieved from http://www.dlc-ubc.ca/wordpress_dlc_mu/edcp562/files/2011/09/Currere.pdf

Pinar, W. F. (1975). The Method of “Currere”. ERIC.

Pinar, W., Reynolds, W., Slattery, P., \& Taubman, P. (2008). Understanding Curriculum. New York: Peter Lang Publishing.

Portfolio planning and implementation. (2011). Retrieved from http://www.esl-literacy.com/sites/default/files/Portfolio\%20Planning\%20and\%20Implementation_ $0 . p d f$

Tannenbaum, J. (1997). Practical ideas on alternative assessment for ESL students. ERIC Digest. 